\title{
A study on potential standing cabin effects in improving the competitiveness of low-cost airlines
}

\begin{abstract}
The main market competition between the airlines today has changed towards the affordability of the offered air transportation service. In other words, airlines are competing to lower their ticket prices as to capture high demands from leisure and business travelers, who are also price-sensitive customers. Theoretically, by having more passengers onboard the aircraft, flight ticket price can be lowered since the imposed operational costs can be shared by more passengers per flight. To achieve this, an idea of standing passenger cabin whereby the passengers are transported in the aircraft cabin in their upright position has been proposed to reduce the operational flight costs and hence the charging ticket price to the passengers. This paper explores the practicality of such idea with an example case study that is focused on domestic flights market in Malaysia. All in all, it can be concluded that the standing cabin idea has a potential to be applied by low-cost airlines servicing short-haul flight markets.
\end{abstract}

Keyword: Standing cabin; Vertical seat; Low-cost airlines; Aircraft cabin; Passenger cabin 